\title{
STABILIZATION OF VIBRO-THERMAL PROCESSES DURING POST-PRODUCTION TESTING OF ROLLING BEARINGS
}

\section{Bartosz JAKUBEK, Roman BARCZEWSKI, Wojciech RUKAT, Leszek RÓŻAŃSKI, Mateusz WRÓBEL}

Poznan University of Technology, Faculty of Mechanical Engineering and Management, Poznan, Poland, bartosz.jakubek@put.poznan.pl, roman.barczewski@put.poznan.pl, wojciech.rukat@put.poznan.pl, leszek.rozanski@put.poznan.pl, mateusz.wrobel@ put.poznan.pl

\section{Summary}

In the process of post-production testing of rolling bearings, quality classification and/or qualification of finished products as good and defective is performed. In view of mass production, bearing testing should be carried out within a short period of time. Vibroacoustic (VA) processes are widely used for post-production testing. Parameterization of bearing vibrations is largely determined by stabilization of lubrication conditions and VA processes, which to some extent depend on temperature. The article presents the results of temperature measurements carried out during the testing of a set of new tapered roller bearings. On their basis, an attempt was made to estimate the value of rms values of bearing vibration accelerations. This is based on the known relationships between the temperature and viscosity of the oil as well as the relationship between viscosity and acceleration of the bearing vibrations. The estimated acceleration values were verified experimentally. The time after which the temperature of a bearing is stabilized was also determined. The paper also shows the influence of a lubricant on these processes, mainly its kinematic viscosity.

Keywords: stabilization of temperature and vibrations, post-production testing, rolling bearings

\section{STABILIZACJA PROCESÓW WIBRO-TERMALNYCH PODCZAS TESTOWANIA POPRODUKCYJNEGO ŁOŻYSK TOCZNYCH}

Streszczenie

W procesie testowania poprodukcyjnego łożysk tocznych dokonywana jest klasyfikacja jakościowa i/lub kwalifikacja gotowych wyrobów jako dobre i wadliwe. W związku z masową produkcją, testowanie łożysk powinno się zawierać w krótkim przedziale czasu. Do testowania poprodukcyjnego powszechnie stosowane są procesy wibroakustyczne (WA). Parametryzacja drgań łożysk determinowana jest w dużej mierze przez stabilizację warunków smarowania a także procesów WA, które w pewnym stopniu zależne są od temperatury. $\mathrm{W}$ artykule przedstawiono wyniki pomiarów temperatury przeprowadzone podczas testowania zestawu nowych stożkowych łożysk tocznych. $\mathrm{Na}$ ich podstawie podjęto próbę oszacowania wartości skutecznych przyspieszeń drgań łożysk. Oparto się przy tym na znanych zależnościach pomiędzy temperaturą a lepkością oleju jak i zależnością pomiędzy lepkością a przyspieszeniami drgań łożysk. Oszacowane wartości przyspieszeń zostały zweryfikowane eksperymentalnie. Określono również czas, po którym następuje stabilizacja temperatury łożyska. Pokazano też, jaki wpływ na te procesy ma środek smarny głównie zaś jego lepkość kinematyczna.

Słowa kluczowe: stabilizacja temperatury i drgań, testowanie poprodukcyjne, łożyska toczne

\section{INTRODUCTION}

In order to achieve a long service life and reliability of rolling bearings, it is important to ensure an appropriate operating policy [1, 2]. It includes the use of methods for diagnosing the technical condition of bearings [3, 4], while in terms of maintenance it mainly concerns lubrication [5]. The way a lubricant is supplied to a bearing, the type of lubricant and the frequency of its replacement depend on the design of the bearing node, the load and the nature of the bearing operation [6, 7]. Periodic assessment of the technical condition of rolling bearings during operation is usually carried out for the established thermal conditions of the bearing node resulting from the typical operating conditions of the equipment [8].

Tests of new bearings are carried out in transient conditions. This applies in particular to thermal measurements and the stability of lubrication conditions associated with lubricant distribution. These factors may have a significant impact on the outcome of post-production testing. Determining the thermal equilibrium of a node is desirable for assessing the condition of bearings, both during post-production tests and during operation. An exception to this is the performance 
of bearing condition monitoring based on temperature measurements [9, 10]. Many factors influence the temperature of bearing nodes. These include bearing type and size and its operating conditions (including lubrication, slackness, load, rotational speed), heat transfer conditions and thermal properties of the components of the node [11]. It should be noted that proper quality assessment of brand-new bearings and their qualification (good/defective) is important in terms of operational reliability of machinery and equipment.

Post-production tests, due to the high pace of the production cycle and the resulting limited time available, last up to a maximum of several seconds. It can therefore be assumed that the bearings subjected to the inspection tests do not achieve their thermal stability. For continuous testing of bearings under production conditions we can assume that the measuring stand has a fixed temperature. However, the temperature of the tested bearings is different from the temperature of the stand and will change during the tests. Simplified thermal balance of the bearing installed in the test stand is shown in Fig. 1.

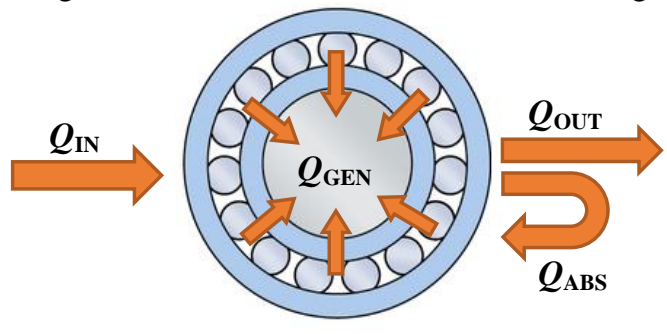

Fig. 1. Thermal balance of a rolling bearing during the post-production test

The energy balance of the tested bearing in thermal terms can be written in the form of the following equation:

$$
Q_{I N}+Q_{G E N}=Q_{A B S}+Q_{O U T}
$$

where: $Q_{\mathrm{IN}}-$ supplied heat (via shaft / bearing housing),

$Q_{\mathrm{GEN}}$ - generated heat (friction),

$Q_{\text {ABS }}$ - absorbed heat - used to change the temperature of the bearing,

$Q_{\text {out }}$ - emitted heat, transferred to other parts of the appliance, lubricant and/or radiated to the environment.

The heat produced by the bearing is generated by the bearing as a result of repetitive elastic deformations of the raceway and rolling elements. The heat conduction equation, which binds the mechanical state (deformations and stresses) to the temperature, has the following form [12]:

$$
\alpha \rho c_{p} \nabla^{2} T-\rho c_{p} \dot{T}=-\beta \sigma \dot{\varepsilon}_{p}+\frac{k E T_{0} t_{r}\left(\dot{\varepsilon}_{e}\right)}{1-2 v}
$$

where: $\alpha$ - thermal conductivity,

$\rho$ - density,

$c_{\mathrm{p}}$ - specific heat,

$\beta$ - rate of conversion of deformation energy to heat energy, $\sigma-$ stress

$\dot{\varepsilon}_{p}-$ plastic strain rate,

$k$ - heat emission coefficient,

$E$ - Young's modulus,

$T$ - temperature,

$T_{0}-$ initial temperature or ambient temperature,

$\dot{\varepsilon}_{e}-$ elastic strain rate

$v$ - Poisson's ratio.

The heat generated by the bearing in motion, according to the operating principle, is proportional to the moment of friction $M_{\mathrm{F}}$ and the angular distance travelled $\varphi$, and indirectly to the number of revolutions. The frictional moment depends, among other things, on the design of the bearing itself, the way it is lubricated and the load. The work of friction is equivalent to the heat generated in the bearing and is expressed by the formula [13].

$$
L=M_{f} \cdot \varphi=F \times f_{r}\left(\frac{D+d}{4}\right) \cdot \varphi
$$

where: $L-$ work of friction,

$M_{\mathrm{f}}-$ moment of friction of the bearing,

$\varphi$ - relative angular distance travelled

$f_{\mathrm{r}}$ - rolling friction arm (value determined individually for a given bearing type, in case of tapered roller bearings it is 0.0018) $D$ - bearing outer diameter, $d$ - bearing inner diameter.

There are many definitions of temperature stabilization [14]. Generally, rolling bearing temperature stabilization means a situation in which in the same time unit the sum of thermal energy supplied from outside to the bearing and generated in the bearing is equal to the energy emitted by the bearing node (all heat transfer processes: radiation, conductivity and convection are involved in heat transfer). At the same time the bearing does not absorb heat to change its own temperature.

In this work, the temperature stabilization of a new bearing (without the influence of degradation processes) was defined as a state in which for each time increase $\Delta t$ greater than zero, the temperature increase $\Delta T$ approaches zero, while in practice it is smaller than the criterion value $C_{\mathrm{T}}$ assumed in the given conditions. This state is illustrated in Figure 2 and described by equation (4)

$$
\bigvee_{t_{p}} \bigwedge_{\Delta t>0}\left|T_{\left(t_{p}+\Delta t\right)}-T_{\left(t_{p}\right)}\right| \leq C_{T}
$$

where: $T$-temperature,

$t_{p}$ - start time of temperature stabilization,

$C_{\mathrm{T}}$ - the width of the acceptable range of temperature variation (considering, inter alia, the accuracy of temperature measurement), it was assumed $C_{\mathrm{T}}=1^{\circ} \mathrm{C}$.

The change in bearing temperature during testing affects the kinematic viscosity of the lubricant because the viscosity of the lubricant is a function of temperature $[6,7]$ and viscosity index - VI [15]. Viscosity index allows to determine the range of viscosity variability of oils as a function of 
temperature and to evaluate the quality of lubricants.

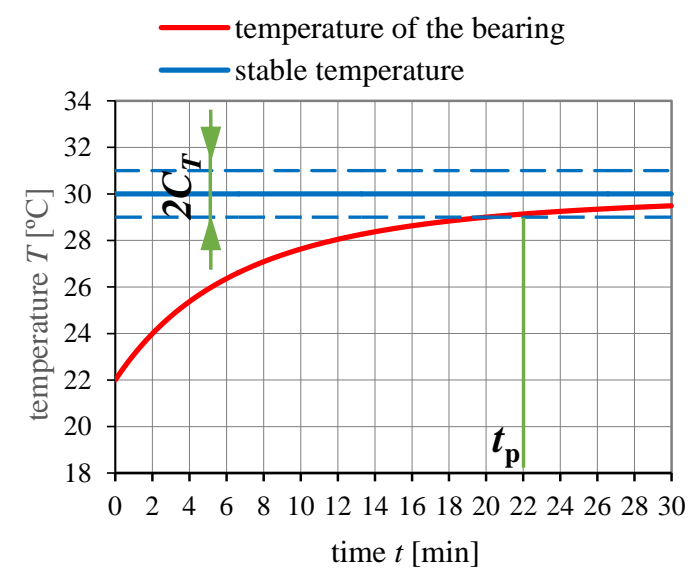

Fig. 2. Bearing temperature changes, example for determining the temperature stabilization time

Figure 3 gives an overview of the kinematic viscosity as a function of temperature for two oils with different viscosity index values for the same kinematic viscosity value.

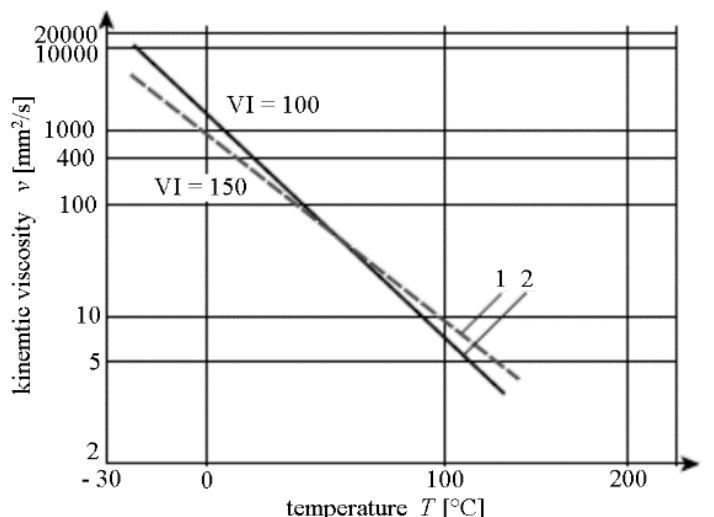

Fig. 3. Changes in viscosity as a function of temperature depending on the viscosity index [16]

Changes in kinematic viscosity caused by temperature changes have a character of a power function. For most common cases, where the temperature range of oils is within the range of $20 \div$ $60^{\circ} \mathrm{C}$ Herschel's formula gives good results [17]. Its form is given by the equation

$$
\mu=\mu_{0}\left(\frac{T_{0}}{T}\right)^{k}
$$

where: $\mu_{0}-$ dynamic viscosity of the oil at the reference temperature $T_{0}$,

$T_{0}$ - reference temperature,

$T$-temperature,

$k$ - temperature directional coefficient of change in viscosity.

Moreover, as shown by Jakubek and Barczewski, the change in kinematic viscosity of a lubricant

has a significant influence on the level of vibrations generated by bearings. Changes in vibration acceleration amplitude values $a_{\text {RMS }}$ of bearings due to the change in kinematic viscosity $v$ of the lubricant are also of a character of a power function [18].

With the lubricant viscosity index and $a_{\mathrm{RMS}}(v)$ characteristics, it is possible to estimate the rms values of bearing vibration acceleration depending on the temperature of the oil used.

Knowing the thermal stabilization process and the associated transient vibrations, it is possible to increase the reliability of the assessment of the technical condition of rolling bearings. It is possible to select a lubricant whose time, temperature and viscosity characteristics will be as stable as possible and the influence of thermal phenomena on bearing vibrations will not be significant. On the other hand, the ability of the lubricant to mask vibroacoustic signals should also be considered [18]. The selection of the optimum lubricant is therefore based on two criteria: stabilization of viscosity and quantities parametrizing vibrations. The recommended minimum lubricant viscosity associated with the size and rotation speed of the bearing should also be considered [19].

The aim of this paper is to determine the influence of lubricant viscosity on the stabilization of vibro-thermal processes in the bearing at constant operational parameters (speed, load).

\section{TESTING METHODOLOGY}

The research included simultaneous tracking of vibration and temperature stabilization processes in the tested new rolling bearings during their first start-ups. Such situations occur during postproduction quality tests of manufacturing and assembly of bearings. The tests were carried out in two variants.

Short-term tests (120 seconds) to observe the initial stabilization phase. The results of such an analysis are important for determining the parameters for conducting rapid post-production tests. They are the basis for bearing classification based on vibration measurements. In practical terms, it will be important to determine what is the minimum time required to achieve stabilization of vibration processes using lubricants of different viscosity. This time will determine the moment from the beginning of the test, after which the vibration signal can be treated as quasi-stationary. During this phase (120s), an increase in bearing temperature may occur, resulting in a significant change in the kinematic viscosity of the lubricant. In this period of time there is also a stabilization of vibration processes related to the determination of lubrication conditions. Ten new bearings were subjected to short tests.

Long-term tests included mainly the analysis of thermal phenomena. This was because the short test did not show full temperature stabilization. The tests lasted up to 30 minutes, depending on the lubricant used. They allowed to determine the time needed to reach a stable operating temperature of the bearing at the preset test load. Analysis of 
sequential thermal images made it possible to determine the speed and intensity of heat transfer from the inside of the bearing to its housing. In addition, these tests enabled an overall assessment of the heating process of the test stand. Before each long test, the stand was cooled with an air stream for approx. 100 minutes to an ambient temperature of $24^{\circ} \mathrm{C}$. Two new bearings were subjected to long tests.

Both test variants were conducted on tapered roller bearings type CBK 171 (63174 SKF). The choice of tapered roller bearings was dictated by the possibility of thermographic measurements of all bearing elements. For selected lubricants (ISO VG 7, ISO VG 22, ISO VG 150, ISO VG 460), monitoring of temperature changes of bearing elements was carried out simultaneously with vibration measurements.

Sequential thermograms made with a 1 -minute interval made it possible to track temperature changes in the bearing. It was also possible to determine the time of thermal stabilization of the contact area of rolling elements and bearing raceways, i. e. the place where, among others, tribological processes occur. The temperature in this area has a significant influence on the lubricant properties. Wang and Wang as well as Yan et al. stated that the highest temperature is recorded in the contact area of the raceway and roller, with the indication that this temperature concerns a smaller roller base [20, 21]. This pattern could not be verified due to the construction of the stand. $\mathrm{Li}$, Xue and $\mathrm{Ma}$, on the other hand, stated that the maximum temperature is reached by the inner ring of the bearing [22].

Before each test was started bearings were carefully prepared in accordance with the established procedure [23]. First, bearings were cleaned in an ultrasonic cleaner with kerosene (3 min) and then rinsed in petroleum ether. The cleaning procedure was repeated twice. After each bearing had been mounted on the test stand, $0.25 \mathrm{ml}$ of oil was applied before the test began. The lubricant was pre-distributed by several manual turns of the shaft.

The design of the measuring station meant that the bearing outer ring remained stationary during testing, while the inner ring rotated freely. Shortterm and long-term tests were carried out using the same operational parameters:

- shaft speed (bearing inner ring) - $1450 \mathrm{rpm}$,

- axial load $-55 \mathrm{~N}$,

- radial load $-30 \mathrm{~N}$.

The system of vibration acquisition and analysis was used to track the vibration processes, which included:

- piezoelectric transducer of acceleration PCB M352A60 (linear transmission band up to $60 \mathrm{kHz}$ ),

- analogue-to-digital conversion module VIBDaq 4+,
- dedicated measuring and analyzing application, developed in the DASYLab environment.

The following parameters of analogue-to-digital conversion were applied:

- signal quantization 24-bits,

- sampling frequency $f_{\mathrm{s}}=98 \mathrm{kHz}$,

- size of the basic data segment - 8192 samples.

Rapid temperature measurements of bearing components that do not affect temperature distribution, using tactile methods, are rather impossible. Therefore, the FLIR E6 thermal imaging camera was used for short tests. During the short test the thermal image was recorded every 10 seconds. In the case of long tests, the FLIR T620 camera was used, because it has better parameters than the FLIR E6 camera. The spatial (geometric) resolution of the T620 camera in the sense of IFOV (Instantaneous Field Of View) is $0.62 \mathrm{mrad}$ (FLIR E6 - $5.2 \mathrm{mrad}$ ) and the thermal resolution in the sense of NETD (Noise Equivalent Temperature Difference) is less than $0.05^{\circ} \mathrm{C}$ (FLIR E6 - less than $0.06^{\circ} \mathrm{C}$ ). The limiting errors of the two cameras are comparable and equal to $\pm 2^{\circ} \mathrm{C}$ or $\pm 2 \%$ of the temperature readings (the greater of these two values is taken as the limiting error).

Due to low values of metal emission coefficients (and thus also high values of reflectivity coefficients characterizing their radiant properties) it was necessary to cover the lateral surfaces of the outer and inner ring of the bearing with black, matt paint. In this way, the measurement-disturbing ambient radiation reflected from the tested bearing parts, which reaches the camera along with the radiation carrying information about the temperature distribution on the surface of the bearing elements, is significantly reduced [24]. Black matt enamel DX Solution in aerosol was used. Each of the lubricants used covered the rollers and the cage with a layer of such thickness that the emission properties of the metaloil structure were determined by the oil emission properties, which were similar to those of the paint used. It is understood as effective emissivity in the area of spectral sensitivity of the camera, which takes into account spectral properties of the opto-electronic system of the camera and the exitance of the object.

\section{RESULTS}

It was found that within the framework of 2-minute short tests, conducted in various lubrication conditions, vibration stabilization takes place no later than after $45 \mathrm{~s}$. Among the lubricants used there were such ones for which the instantaneous acceleration rms values $a_{\text {IRMS }}$ decreased in the initial phase of the test. These were low viscosity oils. This may be due to the distribution of the lubricant in the bearing during the initial phase of the test. The use of high viscosity lubricants has resulted in an increasing trend in vibration levels. This was probably due to 
changes in temperature and consequently to changes in the viscosity of the oil during the test.

From the point of view of post-production quality control, the optimum lubricant is the lubricant that does not cause significant changes in the measures parameterizing bearing vibrations throughout the entire, albeit short, test period. A situation where changes in the instantaneous rms values $a_{\text {IRMS }}$ are very small was observed when using oils with viscosities between 12 and 100 $\mathrm{mm}^{2} / \mathrm{s}$. It should be noted that oils with a kinematic viscosity within this range are recommended for post-production testing in accordance with ISO 15242 [25]. Figure 4 shows examples of $a_{\text {IRMS }}$ diagrams showing the cases described above.

As mentioned before, at the same time as vibration measurements, a thermal image of a bearing node was taken every 10 seconds. Figure 5 shows a thermal image recorded at the end of the test, after $120 \mathrm{~s}$ (ISO VG 22 oil was used for lubrication). Based on sequentially (every $10 \mathrm{~s}$ ) performed thermograms and maximum temperature values read within the circle marked in Figure 5, a graph of temperature changes as a function of time was created. This is shown in Figure 6. The marked area contains the tested bearing mounted in the housing and the axial pressure system. The main source of heat in the stand is the sliding bearing housing visible in the upper right-hand corner of Figure 5a. It was not considered in determining the maximum temperature values of the tested rolling bearing.

During the short tests, thermal images were recorded for the bearing in motion (rotary motion). Therefore, in Figure 5a it is not possible to clearly distinguish moving elements, especially rolling elements. However, it can be stated that the highest temperature in the tested bearing was observed in the vicinity of the inner ring.

No temperature stabilization was observed during the 120 -second test. The temperature rises the faster the higher the viscosity of the lubricant. This was confirmed by the results of other empirical studies [26, 27] as well as simulation studies [28]. In order to determine the time of temperature stabilization long-term tests were carried out.

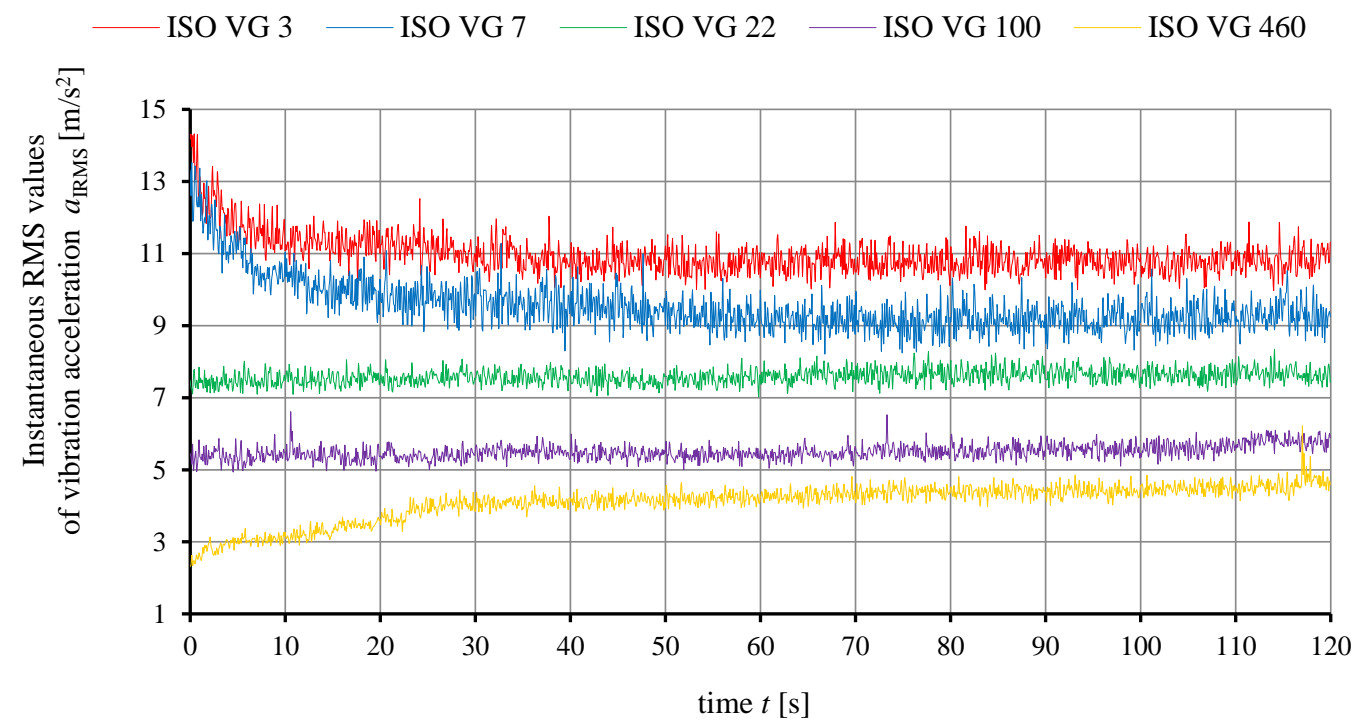

Fig. 4. Instantaneous rms values of vibration acceleration of bearing housings determined for oils of different viscosities

a)

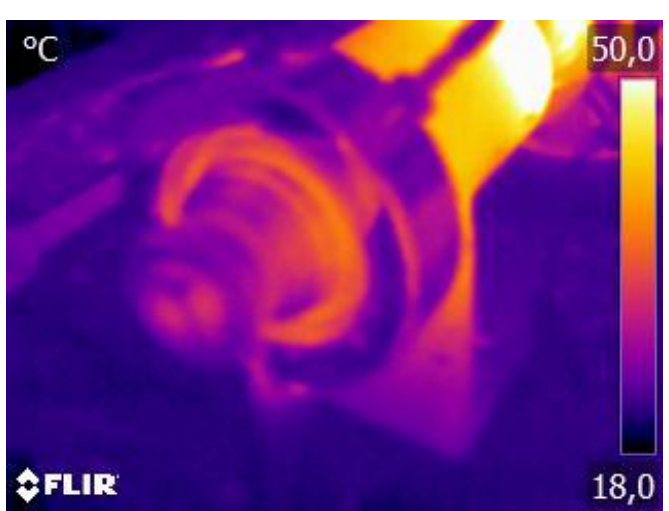

b)

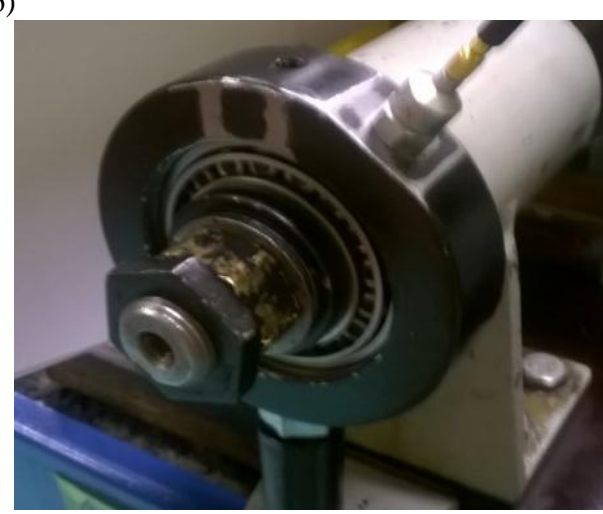

Fig. 5. Tested bearing lubricated with ISO VG 22 oil, a) thermal image after $120 \mathrm{~s}$ from the beginning of the test, $b$ ) view of the bearing in the housing 


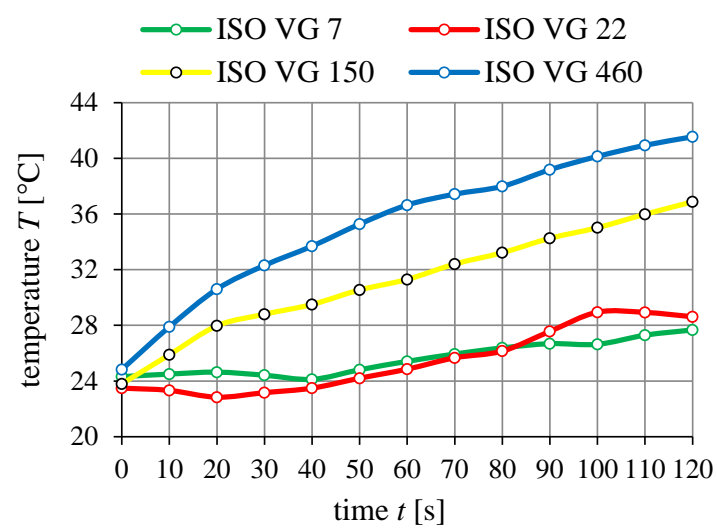

Fig. 6. Bearing node temperature change during a shortterm test $(120 \mathrm{~s})$ for selected lubricants

The dependence of the maximum temperature of rolling elements of the bearing as a function of time, for four selected values of kinematic viscosity of the lubricant is shown in Figure 7. Thermal stability is achieved, and its time depends on the viscosity of the oil used. The nature of the individual diagrams is similar to each other. The bearing temperature asymptotically approaches a value dependent on the type of the lubricant [29, 30]. The highest temperature increase of approx. $35^{\circ} \mathrm{C}$ in relation to ambient temperature was recorded for oil with viscosity of $460 \mathrm{~mm}^{2} / \mathrm{s}$. The lowest temperature increase was observed for oil with kinematic viscosity of $7 \mathrm{~mm}^{2} / \mathrm{s}$, for which it was about $26^{\circ} \mathrm{C}$.

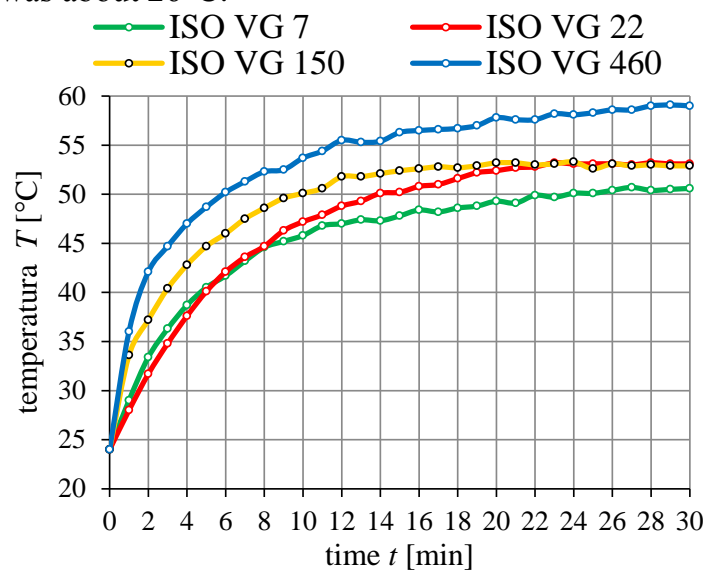

Fig. 7. Temperature stabilization of rolling elements for selected lubricants (long term test $30 \mathrm{~min}$ )

Thermal stabilization curves are based on a series of thermal images from the FLIR T620 camera. During the test, every 60 seconds the bearing drive was stopped for approx. 2 seconds and a picture of the stationary bearing was taken, after which the drive was restarted. This procedure enables selective analysis of thermogram's content, as well as noting the temperature of roller element that was covered with black paint. It also prevents averaging of the temperature in the area of rolling elements as it happens while taking pictures of a rotating bearing. Figure 8 shows examples of thermal images obtained during and after the test using ISO VG 22 oil. During the tests it was found that the highest temperature in the bearing is reached by the rolling elements and the cage. This is clearly visible in Figures $8 \mathrm{a}, 8 \mathrm{~b}$ and $8 \mathrm{c}$. The brightest areas are the bases of the cones (rolling elements) with the high emissivity coating (see arrow, Figures 8c and 8d) and the cage which is not visible in the picture on the right. Its internal surfaces are in the gaps between the rolling elements.

As in the case of short tests, during the long tests the vibration accelerations of the bearing housings were recorded simultaneously.

\section{ESTIMATION OF VIBRATION ACCELERATION VALUES BASED ON OIL TEMPERATURE}

From a practical point of view, it would be very useful to obtain vibro-thermal characteristics allowing to determine the influence of the temperature of the tested bearing on the level of vibrations emitted by it. A procedure for estimating the rms values of vibration accelerations based on the measured temperature of the lubricant, taking into account its kinematic viscosity is shown in Figure 9. Figure 10 shows an example of reading oil viscosity from the function diagram $v(T)$ at any temperature where the viscosity index VI is known.

With the viscosity class of the oil used and its viscosity index, the corresponding curve can be identified and then the viscosity of the oil can be read at the desired temperature. In Figure 10, the red line shows the function $v(T)$ of an oil of viscosity class $100\left(v\left(40^{\circ} \mathrm{C}\right)=100 \mathrm{~mm}^{2} / \mathrm{s}\right)$ and a viscosity index $\mathrm{VI}=95$.

It should be noted that the described idea of estimating the vibration acceleration values of bearings requires the determination of the $a_{\mathrm{RMS}}(v)$ characteristic. Relationship (see yellow box in Fig. 9)

$$
a_{R M S}=11.884 v^{-0.161}
$$

where $a_{\mathrm{RMS}}-$ rms value of vibration accelerations, $v$ - kinematic viscosity of the oil,

is the result of a series of tests described in a previous paper by the authors [18]. Estimation based on formula (6) will be possible provided that the same test stand and bearing type (in this case CBK 171) are used and the same operating parameters (rotational speed, load) are guaranteed.

Table 1 presents the results of temperature measurements of the tested oils and the estimated rms values of accelerations.

Estimated rms values of bearing vibration accelerations have been validated with the results of vibration measurements carried out concurrently with temperature measurements. Figure 11 shows the variation of the instantaneous values of the rms values of vibration accelerations of a bearing lubricated with ISO VG 150 oil. Figure 11 shows changes in the rms values of vibration accelerations as a function of time $a_{\text {RMS }}(t)$ with addition of instantaneous $a_{\text {RIRMS }}(t)$ values determined with 
different aggregation coefficient $\mathrm{k}$, which controls the process of current mean-square averaging according to the formula:

$$
a_{I R M S, j}=\sqrt{\frac{1}{k} \sum_{i=1}^{k} a_{j i}^{2}},
$$

where: $i$ - sample number,
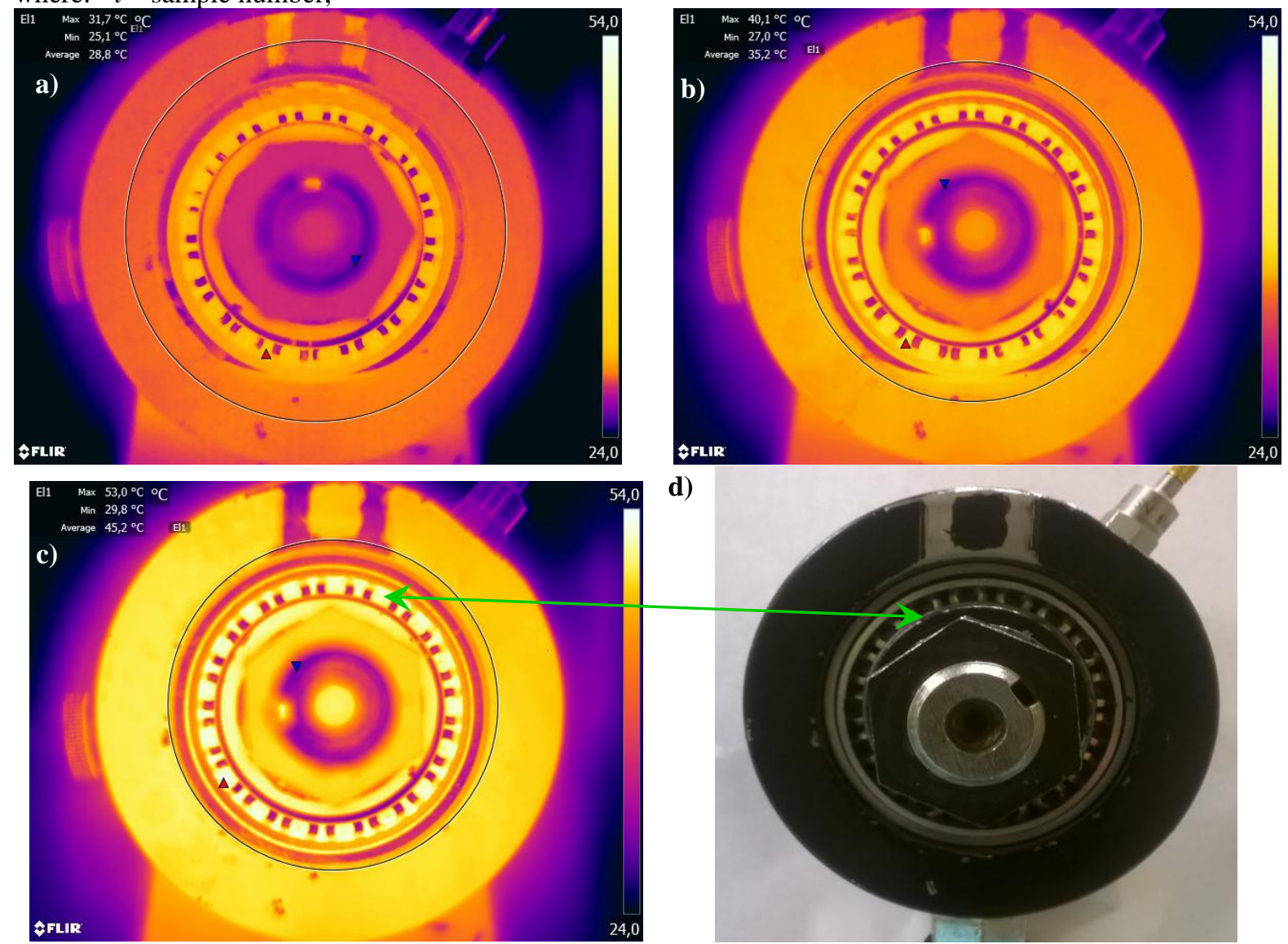

Fig. 8. Tested bearing in a housing lubricated with oil ISO VG 22; thermal image after: a) 2 min, b) 5 min, c) $27 \mathrm{~min}$ of the test, and d) view of the bearing in the housing

\begin{tabular}{|c|c|c|c|}
\hline Oil viscosity class & \multirow{4}{*}{$\begin{array}{l}\text { The dependence } \\
\text { between oil } \\
\text { viscosity and its } \\
\text { temperature, } \\
\text { a graph } \\
\text { (see Fig. 10) } \\
v(T)\end{array}$} & \multirow{2}{*}{$\begin{array}{c}\text { Temperature } \\
T\end{array}$} & \multirow{3}{*}{$\begin{array}{l}\text { The dependence between } \\
\text { vibration accelerations and oil } \\
\text { viscosity [18] } \\
a_{R M S}=11.884 v^{-0.161} \\
\text { Formula applicable only for } \\
\text { new undamaged bearings }\end{array}$} \\
\hline the intercept & & & \\
\hline $\begin{array}{l}\text { Temperature } \\
\text { viscosity index }\end{array}$ & & Kinematic & \\
\hline the slope & & $v$ & $a_{R M S}$ \\
\hline
\end{tabular}

Fig. 9. Diagram for estimating vibration acceleration values based on temperature measurements of the lubricant used

Table 1. Results of estimation of rms values of vibration accelerations based on oil temperature measurements

\begin{tabular}{|l|c|c|c|c|c|c|}
\hline $\begin{array}{l}\text { Oil } \\
\text { designation and } \\
\text { viscosity class } \\
\left(400^{\circ} \mathrm{C}\right)\end{array}$ & $\begin{array}{c}\text { Initial } \\
\text { temperature }\end{array}$ & $\begin{array}{c}\text { Final } \\
T_{0}\left[{ }^{\circ} \mathrm{C}\right]\end{array}$ & $\begin{array}{c}\text { temperature } \\
T_{1}\left[{ }^{\circ} \mathrm{C}\right]\end{array}$ & $\begin{array}{c}\text { Initial viscosity } \\
v\left(T_{0}\right)\left[\mathrm{mm}^{2} / \mathrm{s}\right]\end{array}$ & $\begin{array}{c}\text { Final viscosity } \\
v\left(T_{1}\right)\left[\mathrm{mm}^{2} / \mathrm{s}\right]\end{array}$ & \multicolumn{2}{|c|}{$\begin{array}{c}\text { Estimated rms value of vibration } \\
\text { accelerations }\end{array}$} \\
\hline ISO VG 7 & 24 & 50 & 10 & 5 & 8,20 & 9,17 \\
\hline$I_{\mathrm{RMS}}\left(v\left(T_{0}\right)\right)\left[\mathrm{m} / \mathrm{s}^{2}\right]$ & $a_{\mathrm{RMS}}\left(v\left(T_{1}\right)\right)\left[\mathrm{m} / \mathrm{s}^{2}\right]$ \\
\hline ISO VG 150 & 24 & 53 & 36 & 14 & 6,67 & 7,77 \\
\hline ISO VG 460 & 24 & 53 & 280 & 60 & 4,80 & 6,15 \\
\hline
\end{tabular}




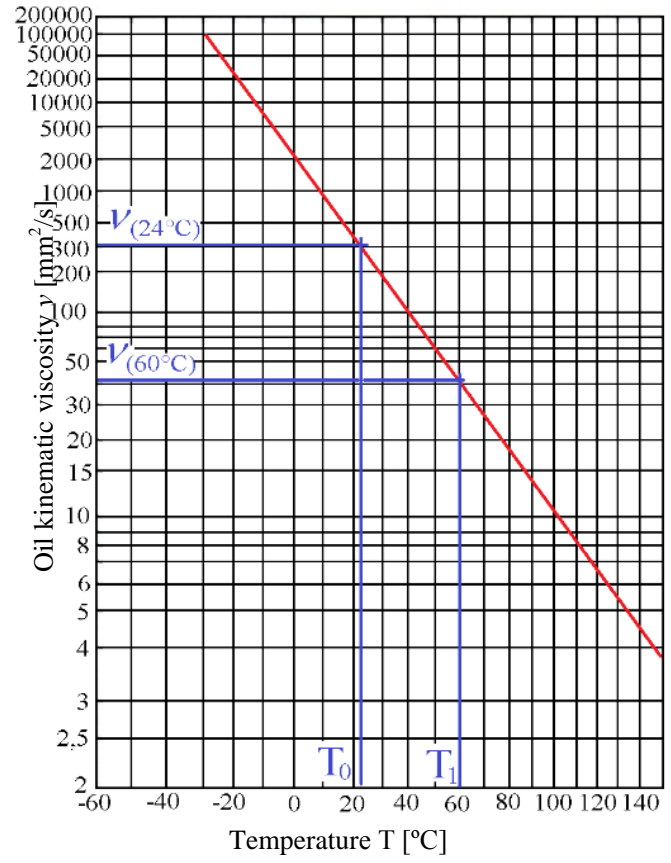

Fig. 10. Example of using the graph of function $v(T)[16]$

Changing the (mean square) averaging interval time smooths the curve. The longer the averaging time, the less important are high-energy impulse phenomena and the smaller is the local range of $a_{\text {IRMS }}$ variation. As temperatures rise and lubricant viscosity decreases, the $a_{\mathrm{IRMS}}$ values increase. A decrease in bearing vibration amplitudes along with an increase in lubricant viscosity was also observed in other cases [18, 31, 32].

In the case shown in Figure 11, the recorded instantaneous rms values of the vibration accelerations in the initial test phase are less than $5 \mathrm{~m} / \mathrm{s}^{2}$, whereas at the end of the test the $a_{\text {IRMS }}$ values oscillate around $6.25 \mathrm{~m} / \mathrm{s}^{2}$. As shown in Figure 11, the estimation of acceleration rms values from temperature measurements and data for ISO VG 150 (Table 1) is correct. Table 2 presents the results of vibration measurements in comparison to the values previously estimated for oils with other viscosities.

The results of the measurements allow us to conclude that estimating the rms values of vibration accelerations based on temperature measurements is possible. The acceleration values corresponding to viscosities between 5 and $300 \mathrm{~mm}^{2} / \mathrm{s}$ were estimated with at least satisfactory accuracy. The results with the smallest estimation errors are highlighted in color in Table 2.

Moreover, it was found that the rms value of vibration accelerations stabilizes similarly to the temperature of the lubricant used.

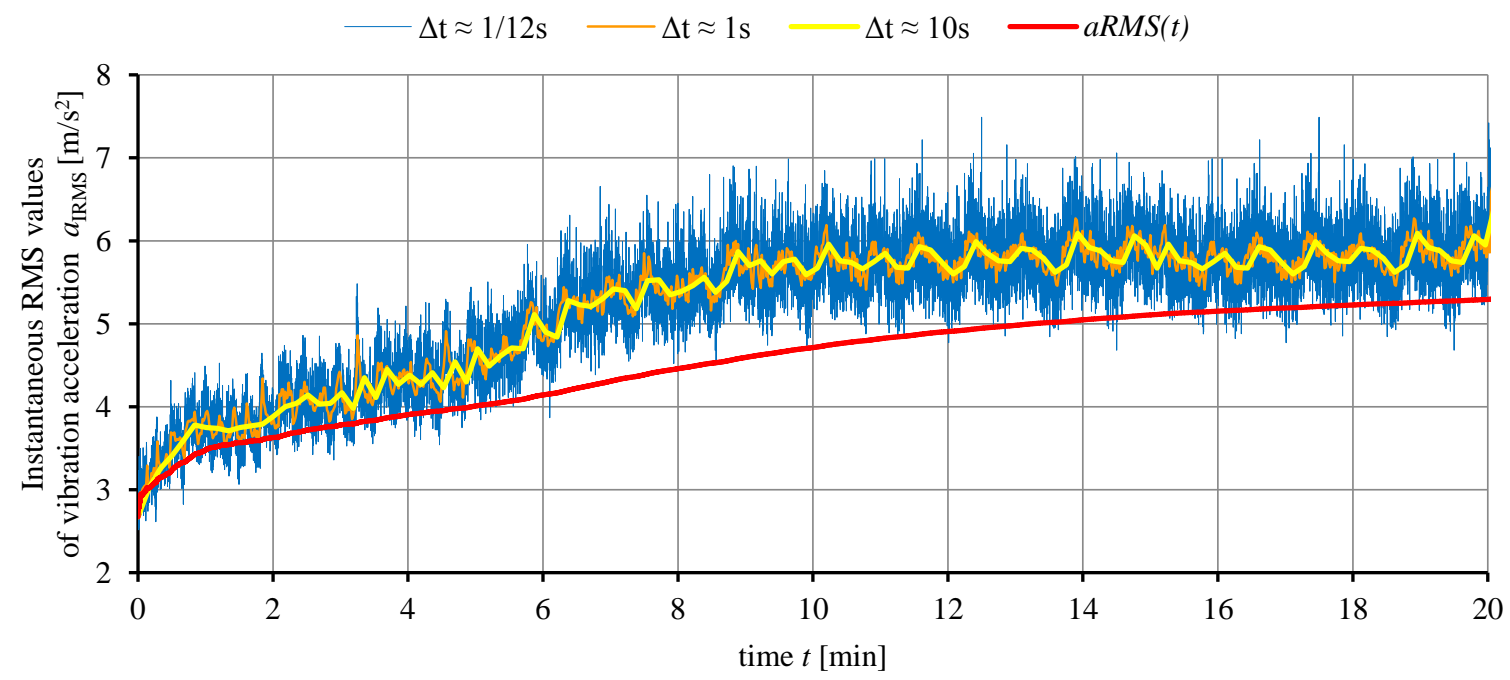

Fig. 11. Instantaneous rms values of bearing housing vibration acceleration, determined for different time periods, when lubricated with oil ISO VG 150

Table 2. Comparison of the estimated rms values of vibration accelerations with the results of measurements

\begin{tabular}{|c|c|c|c|c|c|c|c|c|}
\hline \multirow{2}{*}{$\begin{array}{l}\text { Oil } \\
\text { designation } \\
\text { and } \\
\text { viscosity } \\
\text { class }\left(40^{\circ} \mathrm{C}\right)\end{array}$} & \multicolumn{2}{|c|}{$\begin{array}{l}\text { Estimated rms value of } \\
\text { vibration accelerations }\end{array}$} & \multicolumn{2}{|c|}{$\begin{array}{l}\text { Measured instantaneous rms } \\
\text { value of vibration accelerations }\end{array}$} & \multicolumn{2}{|c|}{$\begin{array}{l}\text { Initial value } \\
\text { estimation error }\end{array}$} & \multicolumn{2}{|c|}{$\begin{array}{l}\text { Final value } \\
\text { estimation error }\end{array}$} \\
\hline & $\begin{array}{c}a_{\mathrm{RMS}}\left(v\left(T_{0}\right)\right) \\
{\left[\mathrm{m} / \mathrm{s}^{2}\right]}\end{array} \mid$ & $\begin{array}{c}a_{\mathrm{RMS}}\left(v\left(T_{1}\right)\right) \\
{\left[\mathrm{m} / \mathrm{s}^{2}\right]}\end{array}$ & $\begin{array}{c}\text { initial } \\
a_{\mathrm{IRMS}}\left(T_{0}\right)\left[\mathrm{m} / \mathrm{s}^{2}\right]\end{array}$ & $\begin{array}{c}\text { final } \\
a_{\mathrm{IRMS}}\left(T_{0}\right)\left[\mathrm{m} / \mathrm{s}^{2}\right]\end{array}$ & $\begin{array}{c}\text { absolute } \\
{\left[\mathrm{m} / \mathrm{s}^{2}\right]}\end{array}$ & $\begin{array}{c}\text { relative } \\
{[\%]}\end{array}$ & $\begin{array}{l}\text { absolute } \\
{\left[\mathrm{m} / \mathrm{s}^{2}\right]}\end{array}$ & $\begin{array}{c}\text { relative } \\
{[\%]}\end{array}$ \\
\hline ISO VG 7 & 8,20 & 9,17 & 9,25 & 10,20 & 1,05 & 11,35 & 1,03 & 10,10 \\
\hline ISO VG 22 & 6,67 & 7,77 & 6,86 & 7,58 & 0,19 & 2,77 & 0,19 & 2,51 \\
\hline ISO VG 150 & 4,80 & 6,15 & 4,57 & 6,43 & 0,23 & 5,03 & 0,28 & 4,35 \\
\hline ISO VG 460 & 3,91 & 5,30 & 2,82 & 5,28 & 1,09 & 38,65 & 0,02 & 0,38 \\
\hline
\end{tabular}




\section{SUMMARY}

The results of the research carried out within the framework of this work have led to the following conclusions.

It is possible to estimate the rms values of vibration accelerations based on temperature measurements. For this it is necessary to know the parameters of the oil used and to determine the $a_{R M S}(v)$ curve experimentally.

It is possible to obtain momentary stabilization of bearing vibrations during post-production testing. Under the discussed test conditions, it took place no later than 45 seconds after the start of operation of the stand and it lasted for about 60 seconds. A similar pattern has been observed in this context in previous studies. These times depend on the condition of the bearing and the properties of the lubricant used.

Temperature stabilization (as determined by formula (4)) takes place no sooner than after 15 minutes. This occurs after the same time from the start of operation of the test stand for each tested lubricant, whereas the final temperature depends on the viscosity of the oil. Vibration stabilization observed in the long-term test $(30 \mathrm{~min}$ ) occurs the faster the lower the viscosity of the oil used. Vibration stabilization takes place at different $a_{\text {RMS }}$ values depending on the viscosity grade of the oil used. It was confirmed that the amplitudes of vibrations decrease with increasing viscosity of the oil used.

Temperature stabilization does not occur in the short test (120 s). When using low viscosity oil, no noticeable temperature changes were recorded for the first 30 seconds of the test. The use of an oil with kinematic viscosity between 10 and $50 \mathrm{~mm}^{2} / \mathrm{s}$ allows to omit the influence of temperature changes and lubricant viscosity on vibrations. They can therefore be recommended for testing as part of post-production rolling bearing inspection.

\section{SOURCE OF FUNDING}

The results presented are results of the research that was funded with grant $02 / 21 / \mathrm{DSPB} / 3515 / 2018$ for education allocated by the Ministry of Science and Higher Education of the Republic of Poland.

\section{REFERENCES}

1. Radkowski S. Gumiński R. Proactive strategy maintenance. Scientific Journal of Silesian University of Technology. Series Trans-port 2014; 82: 193-202. Polish.

2. Legutko S. Fundamentals of exploitation of machines and devices. Warszawa: WSiP; 2004. Polish.

3. Randall R, Antoni J. Rolling element bearing diagnostics - A tutorial. Mechanical Systems and Signal Processing 2010; 25: 485-520. https://doi.org/10.1016/j.ymssp.2010.07.017
4. Randall R. Vibration-based Condition Monitoring: Industrial, Aerospace and Automotive Applications. New Delhi: Wiley; 2011: 67-71.

5. Żabicki D. Lubrication of gears and bearings, Smarowanie i Mechanizmy, addition to the magazine Główny Mechanik 2015; July-August: 30-32. Polish.

6. Mullett G. Grease lubrication of rolling bearings. Tribology 1973; 6: 21-28.

7. FAG Kugelfischer Georg Schäfer AG. Rolling Bearing Lubrication. Publ. No. WL 81 115/4 EA

8. Rao BKN, Handbook of Condition Monitoring, Oxford: Elsevier Advanced Technology; 1996: 97-102.

9. Schulz R, et al. Thermal Imaging for Monitoring Rolling Element Bearings. 12th International Conference on Quantitative Infrared Thermography, Bordeaux, France 7 - 11 July 2014. www.ndt.net/?id=17707

10. Radkowski S. Rolling bearings diagnosing. In. Żółtowski B, Cempel C. eds. Engineering of Machine Diagnostics, Radom: Polskie Toważystwo Diagnostyki Technicznej, Instytut Technologii Eksploatacji PIB; 2004: 525-544. Polish.

11. Różański L, Poloszyk S. The use of thermovision in machine diagnostics. In: Thermovision measurements in practice. Madura $\mathrm{H}$, ed. Warszawa: Agencja Wydawnicza PAKu; 2004: 75-83. Polish.

12. Lerch V, Gary G, Herve P. Thermomechanical properties of polycarbonate under dynamic loading. Journal of Physics IV France 2003;110: 159-164. https://doi.org/10.1051/jp4:20020687

13. http://www.roymech.co.uk/Useful Tables/Tribology/ Bearing\%20Friction.html / online access 05.02.2019

14. Rickman SL, Ungar EK. A physics-based temperature stabilization criterion for thermal testing. 25th Aerospace Testing Seminar, Manhattan Beach, California, USA, 12-15 October 2009. https://ntrs.nasa.gov/archive/nasa/casi.ntrs.nasa.gov/2 0090037689.pdf

15. Covitch MJ, Trickett KJ. How Polymers Behave as Viscosity Index Improvers in Lubricating Oils. Advances in Chemical Engineering and Science 2015; 5: 134-151. http://dx.doi.org/10.4236/aces.2015.52015

16. TOTAL Polska Sp. z o. o. Industrial Lubricants, handbook. Chapter 4 Basic methods of quality assessment of industrial lubricants and their operating meaning. Warszawa 2003. Polish.

17. Stryczek S. Hydrostatic drive, part 1 elements. Warszawa: WNT 2013. Polish.

18. Jakubek B, Barczewski R. The influence of kinematic viscosity of a lubricant on broadband rolling bearing vibrations in amplitude terms. Diagnostyka. 2019; 20(1): 93-102. https://doi.org/10.29354/diag/100440

19. Good RW, Rolling Bearings. In: Lindley R, Higging I, eds. Maitenence Engineering Handbook. New York: McGraw-Hill Book Company; 1988. 6-17-638.

20. Wang A, Wang J. Temperature Distribution and Scuffing of Tapered Roller Bearing, Chinese Journal of Mechanical Engineering 2014; 27(6) 1272-1279. https://doi.org/10.3901/CJME.2014.0813.133

21. Yan K, Wang N, Zhai Q, Zhu Y, Zhang J, Niu Q. Theoretical and experimental investigation on the thermal characteristics of double-row tapered roller bearings of high speed locomotive. International Journal of Heat and Mass Transfer. 2015; 84: 11191130 . 
$\underline{\text { http://dx.doi.org/10.1016/j.ijheatmasstransfer.2014.11 }}$ .057

22. Li J, Xue J, Ma Z. Study on the Thermal Distribution Characteristics of High-Speed and Light-Load Rolling Bearing Considering Skidding, Applied Sciences 2018; 1593(8): 1-20. https://doi.org/10.3390/app8091593

23. Gałęzia A, Barczewski R, Jakubek B. Possibilities of Faults Detection of Rolling Bearings Using Energetic Descriptors of Vibrations Signals. In: Timofiejczuk A, Chaari F, Zimroz R, Bartelmus W, Haddar M, eds. Advances in Condition Monitoring of Machinery in Non-Stationary Operations. Springer; 2018. https://doi.org/10.1007/978-3-319-61927-9_31

24. Więcek B, De Mey G. Infrared thermal imaging. Basics and applications. Warszawa: Wydawnictwo PAK; 2011: 68-80. Polish.

25. ISO 15242-1(2015) Rolling bearings - Measuring methods for vibration - Part 1: Fundamentals

26. Xu J, Zhang J, Huang Z, Wang L. Calculation and finite element analysis of the temperature field for high-speed rail bearing based on vibrational characteristics, Journal of Vibroengineering 2015; 17(2): 720-732.

27. Zhou X, Zhang H, Hao X, Liao X, Hana Q. Investigation on thermal behavior and temperature distribution of bearing inner and outer rings, Tribology International 2019; 130: 289-298. https://doi.org/10.1016/j.triboint.2018.09.031

28. Ai S, Wang W, Wang Y, Zhao Z. Temperature rise of double-row tapered roller bearings analyzed with the thermal network method, Tribology International 2015; 87: 11-22.

http://dx.doi.org/10.1016/j.triboint.2015.02.011

29. Takabi J, Khonsari MM. Experimental testing and thermal analysis of ball bearings, Tribology International 2013; 60: 93-103. https://doi.org/10.1016/j.triboint.2012.10.009

30. Bakoglidis KD, Nedelcu I, Ivanov IG. Rolling performance of carbon nitride-coated bearing components in different lubrication regimes, Tribology International 2017; 114: 141-151. https://doi:10.1016/j.triboint.2017.04.006

31. Jamadar I, Vakharia D. Correlation of base oil viscosity in the grease with vibration severity of damaged rolling bearings, Industrial Lubrication and Tribology 2018; 70(2): 264-272. https://doi.org/10.1108/ILT-04-2016-0078

32. Jakubek B, Barczewski R, Jakubowicz M. The influence of the lubrication on the vibroacoustic signal generated by rolling bearings. Journal of Vibrations in Physical Systems 2017; 28: 1-9.

Received 2019-05-13

Accepted 2019-08-06

Available online 2019-08-12

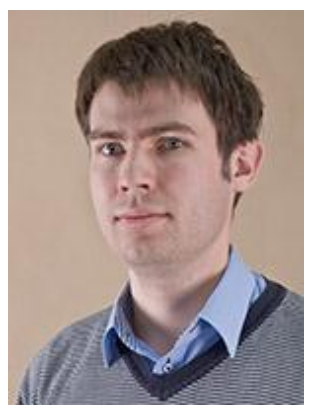

Bartosz JAKUBEK, M. Sc., is an assistant at the Institute of Applied Mechanics of Poznan University of Technology. His scientific interests include diagnostics and vibroacoustics of machinery and devices, maintenance of machinery and mechanical equipment as well as techniques and methods of digital signal processing. In particular, he deals with post-production diagnostics of tapered roller bearings.

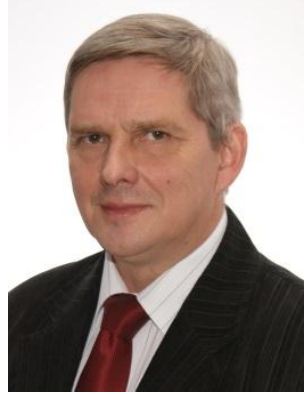

Roman BARCZEWSKI, PhD, is an assistant professor and head of the Systems Diagnostics Laboratory at the Institute of Applied Mechanics of Poznan University of Technology. Specialization: diagnostics and vibroacoustics of machines and environment, techniques and methods of digital signal processing, vibration and noise testing, diagnostic systems. VicePresident of the Polish Society of Technical Diagnostics.

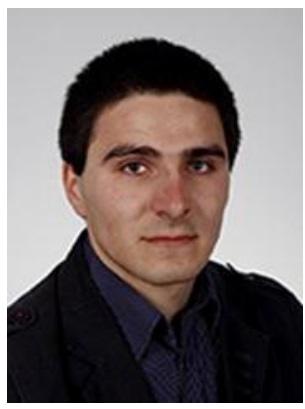

Wojciech RUKAT, M. Sc., is an assistant at the Institute of Applied Mechanics of Poznan University of Technology. The area of his scientific activity is the measurement of vibrations and noise of hand-held power tools, with particular emphasis on those characterized by nonstationary mode of operation.

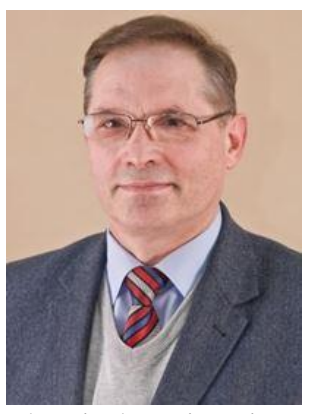

Leszek RÓŻAŃSKI, PhD Post doc in Division of Metrology and Measurement Systems, Institute of Mechanical Technology, Poznań University of Technology, Head of IR thermography laboratory. $\mathrm{He}$ graduated automation control engineering and electrical metrology at the Faculty of Electrical Engineering of PUT and physics at the Faculty of Mathematics, Physics and Chemistry of the Adam Mickiewicz University. He deals with theory and design of thermal imaging systems, thermal diagnosis and applications of vision systems in metrology of geometrical dimensions.

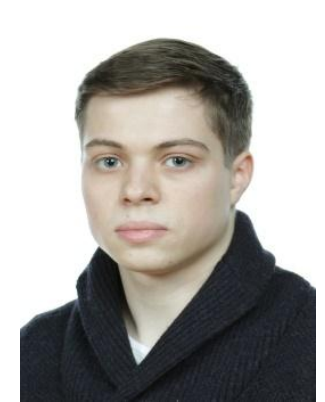

Mateusz WRÓBEL, M. Sc., is an assistant at the Institute of Applied Mechanics of Poznan University of Technology. The area of his scientific activity includes vibroacoustic diagnostics of machines and devices, in particular postproduction diagnostics of asynchronous electric motors. In addition, his interests include electronics and electrical engineering, programming of systems based on AVR and STM32 microprocessors and digital signal processing. 